\title{
USING GAMES IN TEACHING SPECIALIZED VOCABULARY TO MARINE ENGINEERING STUDENTS
}

\section{Valeria Molodtsova ${ }^{1}$}

DOI: https://doi.org/10.30525/978-9934-588-53-2-28

Abstract. High demands to seamen's proficiency in Maritime English requires the use of effective means promoting to improved development of marine students' language skills. Technical vocabulary acquisition is viewed as a key issue in students' mastering Maritime English and improves their prospects of career success. However, due to highlyspecialized nature of Maritime Engineering English vocabulary, many students experience difficulties related to its memorization. Therefore, to find effective ways to overcome this challenge, teachers explore new approaches and methods to teaching Maritime English. Educational games are considered an effective method to contribute to better mastering specialized vocabulary by students. This paper presents the author's study of marine engineering students' perceptions towards using lexical games with the purpose of improved acquisition of the vocabulary within Maritime Engineering English curriculum. Despite the fact that many language experts analyzed the issue of games application in ESP classroom, the studies are still lacking analysis and recommendations on effective game activities for specialized vocabulary acquisition in terms of ME. This research is focused on investigation of the impact of educational games on marine engineering students' motivation, attitudes and cognitive skills development. Besides, this survey established the rating of educational games among the students with regard to the effectiveness of the suggested set of lexical games in technical vocabulary building. The author applied the method of qualitative research involving games, question interview and participants observations. The participants of the study were given an individual Questionnaire with 17 questions assessing their motivation, attitudes, cognitive development and expectation. The

\footnotetext{
${ }^{1}$ Candidate of Pedagogical Sciences,

Associate Professor at the English language Department,

National University “Odessa Maritime Academy”, Ukraine

(C) Valeria Molodtsova
} 
participants were observed during Maritime Engineering classes with the use of a selected set of educational games. The findings demonstrated that the students showed highly positive attitude towards the use of educational games for learning new specialized maritime vocabulary and revision of the vocabulary they already possess. The students noted positive effect of educational games on their memory and cognitive skills. The survey on students' preferences for certain types of educational games for mastering engineering terminology enabled the author to give some practical recommendations on the choice of lexical games that contribute to better specialized vocabulary acquisition. The results of this study provide a field for further investigation of a game-based approach to teaching Maritime Engineering English in higher education with relation to introducing positive changes into the process of improving seafarers' language competency.

\section{Introduction}

Modern maritime industry has raised demands on seamen's skills in terms of their professional competence, intercultural awareness, creative skills, critical thinking, and ability to develop and take decisions in unstable rapidly changing environment. The specialized English language acquisition in higher education implies the development of required competences among students with the account of emerging standards and requirements. Future seamen shall be able to effectively communicate in English both verbally and in written, be capable of interpersonal and cross-cultural interaction. This complex educational task compels lecturers and practitioners to explore new effective methods and approaches to teaching English as a foreign language for special purposes to students.

One of the cardinal factors that contribute to more active and effective acquisition of a foreign language, and is a driving force of educational process, is students' motivation. The implementation of new informational communicative technologies and active methods of teaching promote to students' better perception of new vocabulary and grammar structures. Many language experts believe that one of the most effective ways to enhance students' motivation for learning is creating favorable communicative environment by means of educational games. They provide developing 
learners' language and communicative competences and accelerate mastering educational material $[12$, p. 46].

This paper analyses the issue of using a game-based approach to teaching Maritime English as a variety of English for Specific Purposes (ESP) to students of marine engineering faculty.

Standards of mastering English set by IMO and STCW are stipulated by safety issues. So, safety is closely related to communication in this setting. The communicative competency of a future seaman is of high value in terms of professional success. Maritime English (ME) differs from General English (GE) in specialized terms, specific phrases and set structures that prevail over common words and expressions, some of which are unfamiliar even to the native speaker. In case of Maritime English course for marine engineers, its vocabulary is highly specialized and comprises mainly technical engineering terms. To effectively communicate in real work-related situations, future mariners must possess specific vocabulary knowledge. The richness of vocabulary and language comprehension make up communicative competence [21, p. 46].

However, specific vocabulary acquisition is a challenging task facing a student in the process of studying Maritime English. So, maritime vocabulary needs more focus, which is ensured through active participation of students in vocabulary learning process. To meet the needs of ESP students, teachers implement methods and strategies aimed at effective target vocabulary acquisition.

In contrast to traditional approach to vocabulary teaching, which organizes a class activity around specialized texts, the constructivist learning theory, along with the ensuing situated learning and experiential learning approaches, propagate the ideas of using games for educational purposes $[1$, p. 6]. The vast majority of studies prove that vocabulary is learnt easier with the use of educational games such as puzzles, board games, card games, etc. [21, p. 51; 29, pp. 121-124]. Games keep learners more focused in a relaxed learning atmosphere, thus increasing motivation and building up specialized vocabulary.

While educational games popularity is generally acknowledged in teaching GE to students, the use of game-based approach to teaching ESP is growing too. Though many language experts analyzed the issue of games application in ESP classroom, the studies are still lacking analysis and 
recommendations on effective game activities for specialized vocabulary acquisition in terms of ME.

Thus, this research, along with establishing marine engineering students' perception of educational games in English classroom and qualifying their motivation rise for ME acquisition with the use of games, aims to suggest some ways of raising the level of students' interest and, consequently, their performance in specialized vocabulary mastering through evaluation of certain educational games effectiveness and giving practical recommendations to their implementation within ME course framework.

The questions raised by the study are as follows:

- Do students accept the use of educational games in ME class?

- What factors explain the students' perception of educational games?

- Is the implementation of educational games in teaching maritime English to marine engineering students justified?

- Which games will prove to be the most effective in developing students' language skills, vocabulary mastering in particular (to the participants' point of view)?

In the following section the role of games in ESP classrooms will be discussed in detail.

This paper is organized as follows: the following section discusses the theoretical background of this study. It is followed by Literature Review including games classifications and motivating and demotivating factors of educational games. The next section is devoted to the research methodology. It focuses on the Research Model and participants. Then results and analysis follow. The next section provides the results of the study. And the last contains conclusions and practical recommendations.

\section{Theoretical background}

Empirical investigation of the factors of perception and preference of educational games in terms of specialized vocabulary acquisition on the part of students of Marine Engineering English involves the implementation of motivational activities in the educational process.

Motivation in the second language acquisition is acknowledged to be a key factor in many theories. Affective factors are considered crucial for foreign language learning within motivation theories suggested by Krashen, Carroll, 
Bialystok, Shuman, and others [as cited in 33, pp. 269-271]. However, motivation is viewed by most authors as a multidimensional concept, comprising a set of integrated components. So, Gardner distinguishes cultural beliefs; the individual learner differences (intelligence, aptitude and motivation); the learning contexts, and the outcomes [14, p. 10]. Skehan distinguishes teaching and learning activities; learning outcomes; internal motivation, and extrinsic motivation [32, pp. 49-50]. Crookes also indicates four levels of motivation: microlevel; classroom level; curricular level, and long-term learning outside the classroom [10, pp. 484-495]. D. Madrid proposes a dynamic (changeable with time), cyclical (happening in repeated order) and process-oriented model of motivation, which develops in three phases: pre-actional (initial motivation), actional (process motivation) and post-actional (evaluative) [26, p. 369].

The findings of numerous researches, cited in D. Madrid's paper, identified the strongest motivational strategies, which encourage maximum students' participation, meet their needs and interests and ensure systematic group work:

- the use of audiovisual resources and new technologies;

- group work;

- satisfying the students' needs and interests;

- students' participation in class;

- good grades and fulfilment of the student's success expectations;

- praises and rewards [26, pp. 411-412].

According to Gardner, the use of strategies in class depends on teacher's motivation influences, thus affecting the students' attitudes towards learning [14, p. 10-12].

\section{Literature review}

\subsection{Motivating factors of educational games}

English for specific purposes focuses on teaching a specific kind of English to enable students communicate on professional topics to people belonging to a certain professional community. ESP serves a specific purpose and is characterized by professional terminology, a set of grammar structures, complex syntax and lexical density. Maritime English is a variety of ESP that is used for communication between seamen on board ship, between ships, on land by port officials and individuals working in 
the shipping and shipbuilding industry, etc. So, it involves various contexts related to maritime domain. Comparing to GE, ME demands a teacher to possess specific knowledge of the subject besides having knowledge of the language. The task of a teacher is not only to be proficient in teaching specialized terminology and information in terms of ME course, but to keep the level of students' motivation high thus ensuring their better concentration and learning [2, pp. 3571-3572].

A number of studies on the impact of motivational activities selected according to students' needs proved to be successful in class. These activities, originally created for GE, were modified according to the needs of the ME course. The outcomes demonstrated that the activities used in class developed a positive attitude of students towards such learning and stimulated their participation in class. The students confirmed that they participated more in classes when such activities were used [21, p. 52].

Games keep learners more focused in a relaxed learning atmosphere, thus increasing motivation and building up specialized vocabulary. Games and fun activities serve better retention of teachable vocabulary in learners' memory. Games are valuable pedagogical instrument not only in terms of benefit in students' learning process, but with regard to improving intellectual capabilities of learners. Reilly claimed that the participants who played educational games regularly at the lessons compared to the ones who did not were found to develop increased brain volume [29, pp. 65-66].

There are numerous advantages of implementing game-oriented approach in the ESP classroom:

- Games can distract students from the usual and monotonous routine of the language class; they «....add diversion to the regular classroom activities...» [31, p. 147].

- Games improve learners' acquisition of the English language through motivation and interaction. The competitive nature of games stimulates and encourages students to participate since they want to win. According to Cross [as cited in 15, pp. 127-128], challenge and competition are key factors for any game, which shift learners' attention onto a game as an activity, so language acquisition happens unintentionally.

- Games reduce learning anxiety; relaxed atmosphere encourages shy students to express their opinion without being confused to make a mistake [30, p. 114]. 
- Games encourage students to interact and communicate; they promote a communicative competence. Many games can be played in pairs or in small groups, which gives an opportunity to develop students' interpersonal skills. By asking or answering questions, communicating and discussing some issues in groups or in pairs, students use foreign language to achieve their goals [30, p. 114].

- Through games students practice their language skills in terms of the context of a real modelled professional situation [37, p. 21].

- Games provide a meaningful professional context for learning ESP, thus creating a familiar environment where learners feel confident [30, p. 114].

- Games involve learners' speaking, writing, reading and listening, at the same time. Besides, games develop students' ability of analytical and critical thinking.

- A positive attitude of students towards learning with the use of games is an indisputable fact in the majority of cases, being confirmed both by all researchers referred to in this paper and by the author's personal experience.

- Using games involves interdisciplinary approach. Students use knowledge from other classes, too.

- Games increase students' achievement, namely their test results, ability of communication, vocabulary acquisition, or other language skills get better [25].

- Games are learner-centered activity, since students are actively in-volved in the educational process, which contributes to better perception of teachable material [30, pp. 114-115].

- Games are adaptable for different levels of knowledge and specializa-tion.

- Games promote to collaborative learning but they do not limit students who learn at their own race and cognitive level.

- Educational games do not usually take long time to play and provide immediate feedback in both directions [25].

Generally, games are used as warm-up activities or at the end of the lesson to fill time if left. However, they can be effectively used at all stages of the lesson: when introducing or reviewing vocabulary, when mastering grammar patterns and drilling new structures in speech, etc. [37, p. 21]. According to J. Hadfield [17, p. 4], "a game is an activity with rules, a goal and an element of fun... Games should be regarded as an integral part of the language syllabus". So, games should be treated not only as a 
'fun activity', but as an effective method of educational goals realization [15, pp. 126-129].

\subsection{Demotivating features of educational games}

However, Stojkovic and Jerotijevic pointed out some disadvantages of games, among which there are the following [as cited in 15, p.129]:

- discipline issues, excessive noise and activity;

- inadequate rules instruction can result in playing too much and not achieving the educational goals;

- students may not get involved to equal extent if games are familiar or boring to them;

- games may be treated as unnecessary and childish by some learners.

\subsection{Classifications of educational games}

When choosing language games, a teacher should be guided by several fac-tors, among which there are the game purpose, the students' cognitive level, age and English level, their specific needs, the content of the game. R. Constantinescu notes that language practice should be the central objective of games; at the same time games should be relevant to the curriculum and easy to use in class (as cited in 15, pp. 128-129).

Games appropriateness is one of the key factors providing substantial impact on successful achievement of games educational goals. Games will not bring the desired effect "...when the task or the topic is unsuitable or outside the student's experience" [37, p. 21].

The knowledge on games classifications enables a teacher to make a right choice of game/games with the purpose of the development of certain language skills of students.

There are various games classifications, though all they have much in com-mon. So, F. Stronin mentions categories of games as follows: 1. Lexical; 2. Gram-mar; 3. Phonetic; 4. Spelling; 5. Creative [34, p. 5]. The first four types of games can be referred to language games aimed at development of respective language skills, while creative games imply creative implementation of learnt knowledge and skills in game-like situations.

A. Konysheva subdivides games into types as per their purpose: language and communicative games. According to E. Dushina, linguistic games 
fall into non-communicative, pre-communicative and communicative, depending on the competences to be built [as cited in 25].

J. Hadfield [17, p. 4] classifies language games into linguistic and communicative games. Linguistic games focus on accuracy, while communicative games presuppose information and ideas exchange.

W. Lee [24, pp. 1-4] classifies games into such categories: structure games (training the use of particular patterns of syntax in communication); vocabulary games (focusing mainly on words); spelling games; number games; listen-and-do games; games and writing; miming and role play; discussion games.

Over and above their differences, all classification systems subdivide games into two major categories:

- Games, during which new lexical or grammar material is learnt and certain language skills are trained;

- Games aimed at applying the learnt knowledge and developed skills into non-standard communicative situations in terms of the game context.

One should take into account the principle of didactic sequence: at first, the tasks for learning, memorizing and producing the teachable material are to be completed (including those based on a certain pattern), and only after that creative use of the learnt material follows.

Lexical games are connected with a word, its spelling, meaning, relevance to other lexemes. Lexical games help students to expand their specialized vocabulary by learning new words; remember learnt words better; practice words spelling; activate communicative and mental activity; study words combinations, set expressions, speech patterns.

\section{Methodology \\ 4.1. Research model}

This research methodology is comprised of two stages. The first stage includes the qualitative survey on students' perception of educational games use in Maritime Engineering English classroom with the purpose of specialized vocabulary acquisition. The second stage is devoted to the establishment of students' evaluation of the selected educational games effectiveness in terms of specific maritime vocabulary learning.

The author applied the method of qualitative research, which is viewed by many scholars to be more flexible in data collection, for it enables 
a researcher to obtain detailed information by individual interviewing or through close periodic observation of the process and/or participants [27, pp. 8-11]. Qualitative research ensures an in-depth understanding of participant perception of a survey object, behaviors, attitudes, interactions, etc.

Qualitative data collection instruments used in this research involve games, question interview and participant observations. The "Triangulation" method of data collection, which supposes multiple methods or data sources, provides more detailed and multi-layered information about the study object, analyzing the convergence of information from different sources [7, pp. 141-144].

The participants of the study were given an individual Questionnaire with 17 questions assessing their motivation, attitudes, cognitive development and expectation. The author modified and adapted to the specific needs of the study the sets of questionnaires designed by Ibrahim, R. et al. [19, pp. 213-214].

According to Schmuck [15, p. 131], participant observations help a researcher to control for nonverbal feelings expression, investigate how participants interact with each other with the account of duration of this interaction. Many researchers find participant observation useful in terms of checking the validity of participants' answers to questionnaires through monitoring convergence or divergence of informants' behavior, verbal reactions, and feelings with their interviews results $[15$, p.13; 27, pp. $10-$ 11]. Participants were observed during Maritime Engineering classes with the use of educational games.

\subsection{Participants}

The survey was conducted among first-year and fourth-year students of Marine Engineering English at the Marine Engineering Faculty of the National University “Odessa Maritime Academy”.

The subjects were:

- Group A: 8 first first-year students possessing some knowledge of General English (from A2 to B1 English levels) gained from high school, but without any experience at sea and Maritime English expertise preceding their entering the University;

- Group B: 12 fourth-year students possessing knowledge of both General English and Maritime Engineering English and having sea experience by the time of taking part in the pedagogical experiment. 
The findings of studies on answer formats in survey researches indicate, that including a midpoint in answer formats offers a convenient answer option to respondents who do not strongly agree or strongly disagree with the statement provided and thus deflects positive and negative responses toward the neutral middle point. So, omitting the midpoint option in the answer scale is viewed preferable [13, chapter 3].

Another factor that influenced the author's choice of answer format to ana-lyze the research results was base instability of answer scales, which means the proportion of respondents who change answers between consecutive measurements with identical answer. The more answer options are offered, the more base instability grows. The Likert four verbal format containing no midpoint was reported by experts having lower base instability comparing to other multi-category answer formats [13, chapter 3].

Therefore, the participants were offered to grade their answers on the basis of 4 point Likert verbal scale without midpoint: "Strongly disagree", "Disagree", "Agree", "Strongly agree".

Cronbach's Alpha score for this scale is 0.805 , which shows the reliability of this questionnaire.

The results of the participants' answers are shown in the Table 1 below.

The second stage of this study involved the use of a set of lexical games in class within the framework of the Marine Engineering English course. The games were adapted to the needs of the participants to master technical vocabulary. The subjects were asked to evaluate the effectiveness of these games for acquir-ing/revising technical vocabulary and rank them accordingly. The students were provided the list of the games they had practiced during the pedagogical experiment. The students' rating of the educational games is given in the table 2 .

\subsection{Results and Analysis}

This section analyses the results of the survey using percentage, mean and standard deviations. In terms of student motivation in using educational games for specialized vocabulary acquisition, the participants mostly demonstrated high interest to educational games implementation in their learning now and in future (group A 100\%; Group B 93\%). Students prefer practicing vocabulary with the use of games in contrast to classical way and textbook use (group A 100\%; Group B 92\%). Students were unanimously 


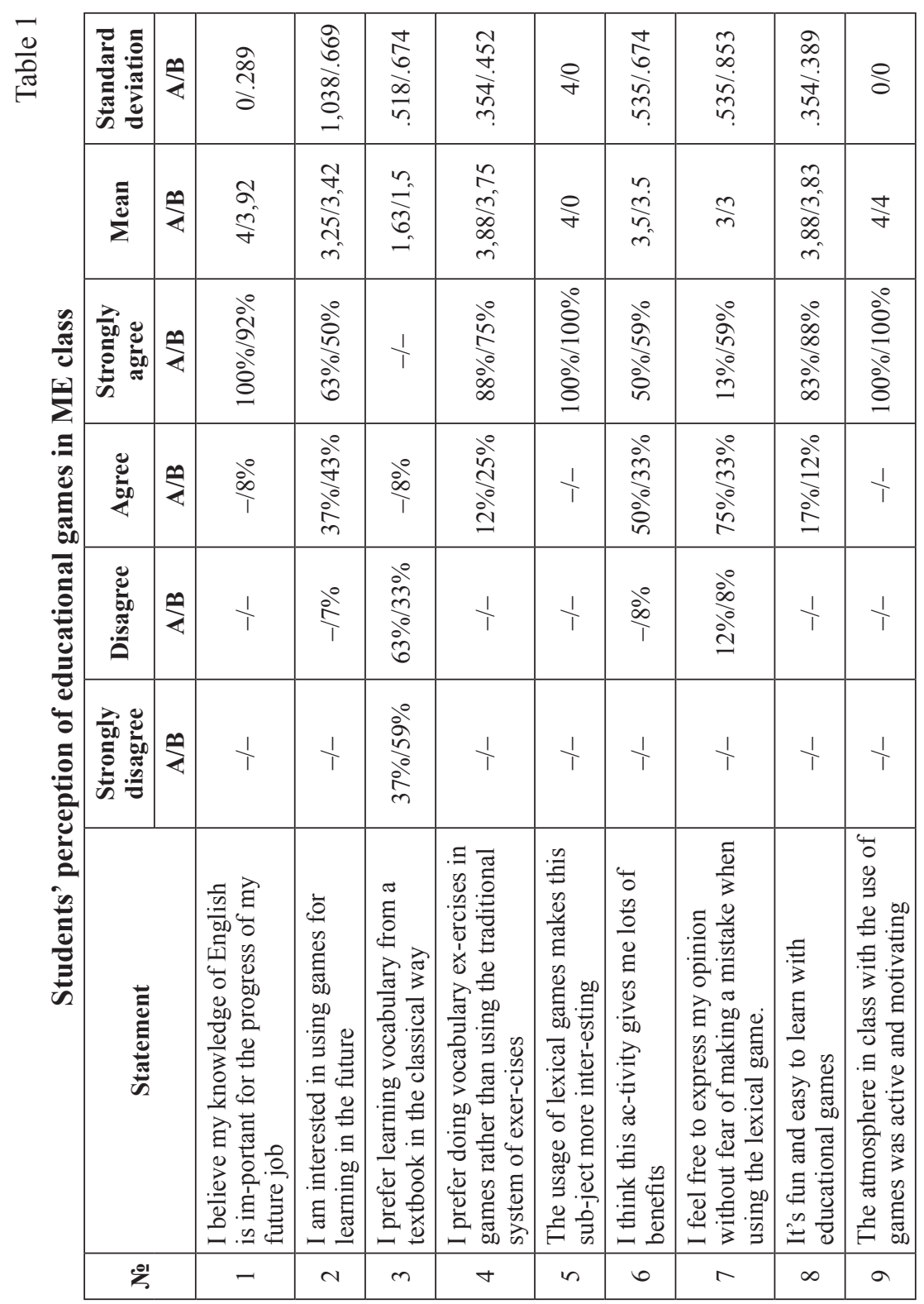




\section{Chapter «Philological sciences»}

\begin{tabular}{|c|c|c|c|c|c|c|c|c|c|}
\hline 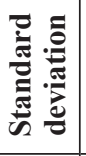 & $\sum_{k}^{\infty}$ & 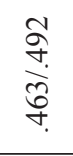 & $\begin{array}{l}\frac{\infty}{N} \\
\frac{\infty}{\infty} \\
\infty \\
n\end{array}$ & $\begin{array}{l}\stackrel{5}{n} \\
\frac{n}{n} \\
n\end{array}$ & 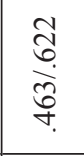 & $\begin{array}{l}\text { तु } \\
\dot{+} \\
\text { ஸे }\end{array}$ & 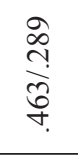 & 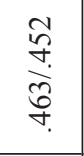 & $\begin{array}{l}\stackrel{v}{r} \\
\frac{\infty}{n} \\
i n\end{array}$ \\
\hline 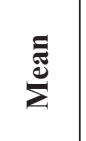 & $\sum_{k}^{\infty}$ & $\begin{array}{l}0 \\
\frac{m}{n} \\
n \\
m\end{array}$ & $\begin{array}{l}0 \\
0 \\
m \\
6 \\
m \\
m\end{array}$ & $\frac{n}{n}$ & $\begin{array}{l}n \\
\text { ñ } \\
\text { ñ } \\
\text { m }\end{array}$ & $\begin{array}{l}n \\
\text { nn } \\
\infty \\
\infty \\
\infty \\
i\end{array}$ & $\frac{\sigma}{n}$ & $\frac{n}{n}$ & $\begin{array}{l}\text { ñ } \\
\text { ma } \\
\infty \\
m \\
m\end{array}$ \\
\hline 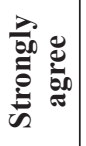 & $\sum_{i}^{\infty}$ & $\begin{array}{l}\frac{0}{\hat{\sigma}} \\
\frac{0}{0} \\
\frac{0}{2}\end{array}$ & $\begin{array}{l}\stackrel{\circ}{0} \\
\frac{0}{\circ} \\
\text { ஸें }\end{array}$ & $\frac{\stackrel{\circ}{+}}{\stackrel{+}{\circ}}$ & $\begin{array}{l}\stackrel{0}{m} \\
\stackrel{m}{0} \\
\text { ò } \\
\text { in }\end{array}$ & $\stackrel{\stackrel{0}{m}}{\stackrel{\rho}{1}}$ & $\begin{array}{l}\stackrel{\circ}{\alpha} \\
\stackrel{\circ}{\circ} \\
\stackrel{2}{2}\end{array}$ & $\frac{\stackrel{0}{i}}{\frac{i}{2}}$ & $\frac{\stackrel{\circ}{+}}{\stackrel{+}{\circ}}$ \\
\hline 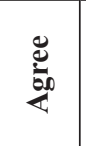 & $\sum_{i}^{\infty}$ & $\begin{array}{l}\stackrel{\circ}{m} \\
\stackrel{2}{\circ} \\
\stackrel{े}{i}\end{array}$ & 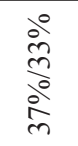 & $\frac{\stackrel{\circ}{+}}{\stackrel{+}{\circ}}$ & $\begin{array}{l}\stackrel{0}{\infty} \\
\stackrel{2}{2} \\
\stackrel{\circ}{i} \\
\frac{1}{2}\end{array}$ & $\begin{array}{l}\stackrel{0}{\infty} \\
\infty \\
\infty \\
\infty \\
\infty \\
\infty\end{array}$ & $\begin{array}{l}\frac{\infty}{\infty} \\
\stackrel{0}{\circ} \\
\stackrel{i}{d}\end{array}$ & $\begin{array}{l}\stackrel{0}{i} \\
\stackrel{2}{0} \\
\stackrel{\circ}{i} \\
\text { ì }\end{array}$ & $\frac{\stackrel{\text { ปे }}{\stackrel{े}{\circ}}}{\text { ते }}$ \\
\hline 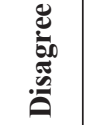 & $\sum_{\gtrless}^{\infty}$ & $\frac{1}{1}$ & $\stackrel{\stackrel{\circ}{N}}{=}$ & $\stackrel{\dot{b}^{\circ}}{=}$ & $\stackrel{\circ}{\grave{1}}$ & 六 & $\frac{1}{T}$ & $\frac{1}{1}$ & $\stackrel{d}{i}_{1}^{0}$ \\
\hline 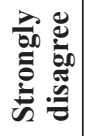 & $\sum_{<}^{*}$ & $\frac{1}{1}$ & $\frac{1}{1}$ & $\frac{1}{1}$ & $\frac{1}{T}$ & $\frac{1}{1}$ & $\frac{1}{1}$ & $\frac{1}{1}$ & $\frac{1}{1}$ \\
\hline$\frac{1}{4}$ & & 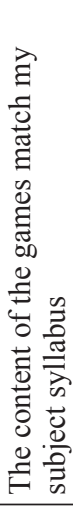 & 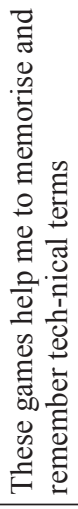 & 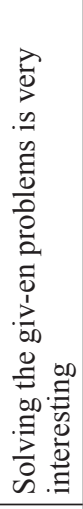 & 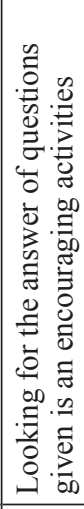 & 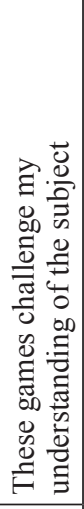 & 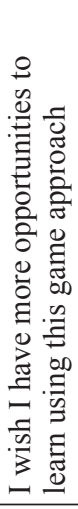 & 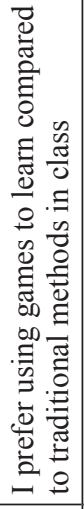 & 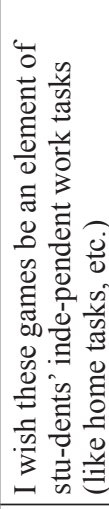 \\
\hline$e^{\circ}$ & & 으 & $=$ & $\simeq$ & $\cong$ & \pm & $\cong$ & $\mathscr{0}$ & 드 \\
\hline
\end{tabular}


Table 2

The list of targeted lexical educational games

\begin{tabular}{|c|c|c|c|}
\hline No & Genre & Game description & $\begin{array}{c}\text { Subject } \\
\text { Area }\end{array}$ \\
\hline 1 & $\begin{array}{l}\text { Guessing } \\
\text { games }\end{array}$ & $\begin{array}{l}\text { Board Race } \\
\text { The teacher draws a line down the middle of the } \\
\text { board and writes a topic on the top. The students are } \\
\text { asked to write as many words related to the topic } \\
\text { as they can in the form of a relay race. Each team } \\
\text { wins one point for each correct word. Unreadable or } \\
\text { misspelled words are not counted. }\end{array}$ & $\begin{array}{c}\text { Technical } \\
\text { vo-cabulary }\end{array}$ \\
\hline 2 & $\begin{array}{l}\text { Guessing } \\
\text { games }\end{array}$ & $\begin{array}{l}\text { Spin the Wheel } \\
\text { The teacher spins the wheel and points a difficult } \\
\text { word. A student has to explain it and gets a point for } \\
\text { the cor-rect answer. If the answer is wrong, another } \\
\text { student is asked until the correct answer is given. }\end{array}$ & $\begin{array}{c}\text { Technical } \\
\text { vo-cabulary }\end{array}$ \\
\hline 3 & $\begin{array}{l}\text { Guessing } \\
\text { games }\end{array}$ & $\begin{array}{l}\text { The Crossword Puzzle } \\
\text { The best clues in crosswords for maritime terms } \\
\text { should be of defining, descriptive and synonymic } \\
\text { character, cryptic clues avoided. }\end{array}$ & $\begin{array}{c}\text { Technical } \\
\text { vo-cabulary }\end{array}$ \\
\hline 4 & $\begin{array}{l}\text { Guessing } \\
\text { games }\end{array}$ & $\begin{array}{l}\text { Hot Potato } \\
\text { Using a ball as "a hot potato", the teacher throws the } \\
\text { "potato" to one of the students and gives a native } \\
\text { lan-guage equivalent of a term or a phrase. The } \\
\text { student that catches the ball has } 5 \text { seconds to give an } \\
\text { English equiva-lent, or he/she is out of the game. If } \\
\text { the answer is cor-rect, the student says another term } \\
\text { in native tongue and throws the potato at someone } \\
\text { else. The last student standing wins the game. }\end{array}$ & $\begin{array}{c}\text { Technical } \\
\text { vo-cabulary }\end{array}$ \\
\hline 5 & $\begin{array}{l}\text { Guessing } \\
\text { games }\end{array}$ & $\begin{array}{l}\text { The Jeopardy Game } \\
\text { This game contains several question categories } \\
\text { (from } 3 \text { to 5), each with five questions ranging from } \\
\text { easy (1) to difficult (5). The teacher draws a grid on } \\
\text { the board. In pairs or small teams, students in turn } \\
\text { choose a category and a difficulty level from } 1 \text { to } \\
5 \text {. The teacher reads out the question. The students } \\
\text { answer the question, and get a point for the correct } \\
\text { answer. If the answer is incorrect, the question stays } \\
\text { in the game for a later round. The game continues } \\
\text { until the last question or when the game time is over. }\end{array}$ & $\begin{array}{c}\text { Technical } \\
\text { vo-cabulary }\end{array}$ \\
\hline
\end{tabular}


(Continuation of Table 2)

\begin{tabular}{|c|c|c|c|}
\hline No & Genre & Game description & $\begin{array}{c}\text { Subject } \\
\text { Area }\end{array}$ \\
\hline 6 & $\begin{array}{l}\text { Guessing } \\
\text { games }\end{array}$ & $\begin{array}{l}\text { The Taboo Game } \\
\text { On separate small pieces of paper, the teacher writes } \\
\text { certain terms related to the topic studied, then folds } \\
\text { it up and puts into a box. Students are divided into } \\
\text { two teams. One student from a team draws a piece } \\
\text { of paper from the box, and tries to describe the term } \\
\text { to his/her team mates, without actually saying the } \\
\text { word or using their native language. If the word is } \\
\text { guessed, the team gets a point. If not, the word goes } \\
\text { back into the box and the player draws the next one. } \\
\text { After } 60 \text { seconds, the teacher counts the number } \\
\text { of correct guesses and gives the turn to the other } \\
\text { team. Each round teams designate another player to } \\
\text { show the term until everyone has a go. The game } \\
\text { continues until the last piece of paper or till the time } \\
\text { is over. }\end{array}$ & $\begin{array}{c}\text { Technical } \\
\text { vo-cabulary }\end{array}$ \\
\hline 7 & $\begin{array}{l}\text { Guessing } \\
\text { games }\end{array}$ & $\begin{array}{l}\text { Association } \\
\text { The teacher writes a technical term on the board. } \\
\text { The students are asked to say the words (nouns, } \\
\text { adjectives and verbs) that associate with this term. }\end{array}$ & $\begin{array}{c}\text { Technical } \\
\text { vo-cabulary }\end{array}$ \\
\hline 8 & $\begin{array}{l}\text { Spelling } \\
\text { Games }\end{array}$ & $\begin{array}{l}\text { A to } \mathbf{Z} \text { Game } \\
\text { The teacher writes the letters of the alphabet in } \\
\text { columns drawn on the board. The class is divided in } \\
\text { pairs or small groups. Each team nominates a writer } \\
\text { to come to the front and write on the board terms } \\
\text { related to a given topic. Prompts from the teams to } \\
\text { their player are en-couraged to let the team complete } \\
\text { the game first. For each letter, only one term can be } \\
\text { written, so the first student claims the letter. That } \\
\text { team wins that has written more terms. In case of } \\
\text { spelling mistakes, the correct spelling is checked } \\
\text { then with the class. }\end{array}$ & $\begin{array}{c}\text { Technical } \\
\text { vo-cabulary }\end{array}$ \\
\hline 9 & $\begin{array}{c}\text { Word } \\
\text { building } \\
\text { and spelling } \\
\text { games }\end{array}$ & $\begin{array}{l}\text { One letter } \\
\text { Students are asked to make new words by changing } \\
\text { one letter in given words. }\end{array}$ & $\begin{array}{c}\text { Technical } \\
\text { vo-cabulary }\end{array}$ \\
\hline 10 & $\begin{array}{l}\text { Word } \\
\text { building } \\
\text { Spelling } \\
\text { games }\end{array}$ & $\begin{array}{l}\text { A missing letter } \\
\text { Students guess the missing letter based on the given } \\
\text { word }\end{array}$ & $\begin{array}{c}\text { Technical } \\
\text { vo-cabulary }\end{array}$ \\
\hline
\end{tabular}


(End of Table 2)

\begin{tabular}{|c|c|c|c|}
\hline No & Genre & Game description & $\begin{array}{l}\text { Subject } \\
\text { Area }\end{array}$ \\
\hline 11 & $\begin{array}{l}\text { Categories } \\
\text { Games }\end{array}$ & $\begin{array}{l}\text { Categories } \\
\text { Students copy the category layout depicted on the } \\
\text { board into their exercise-books. The teacher chooses } \\
\text { a catego-ry, and students write down, as quickly as } \\
\text { possible, terms under the appropriate category on } \\
\text { their answer sheet. The first students to find words } \\
\text { for each category shout 'Stop!', and the game is } \\
\text { over. The students with the most points after a } \\
\text { number of rounds win. }\end{array}$ & $\begin{array}{l}\text { Technical } \\
\text { vo-cabulary. }\end{array}$ \\
\hline 12 & $\begin{array}{l}\text { Matching } \\
\text { activi-ties. }\end{array}$ & $\begin{array}{l}\text { Match up } \\
\mathbf{1}^{\text {st }} \text { variant } \\
\text { Students are asked to match the terms with the } \\
\text { defini-tions. } \\
\mathbf{2}^{\text {nd }} \text { variant (more complex) } \\
\text { In pairs or small groups, students should give as } \\
\text { many definitions as possible to the given specialized } \\
\text { terms, in a specific amount of time (e.g. } 5 \text { minutes). } \\
\text { Then the def-initions' correctness can be discussed } \\
\text { with the class. } \\
\mathbf{3}^{\text {rd }} \text { variant } \\
\text { Students are asked to match up the 1st and last parts } \\
\text { of compound nouns. } \\
\mathbf{4}^{\text {th }} \text { variant } \\
\text { Aimed at checking students' mastering phrasal } \\
\text { verbs used in Maritime English. The teacher designs } \\
\text { two piles of paper slips, one with the verbs (single, } \\
\text { double, bend, stand, heave, steer, bring, etc.), and } \\
\text { the other one with the prepositions (e.g. up, on, by, } \\
\text { for, off, out, etc.). Stu-dents take turns in turning } \\
\text { over a slip from each pile. If the student considers } \\
\text { the combination is a phrasal verb, then he/she } \\
\text { provides the example of its use in a profes-sional } \\
\text { context, and is given a point. The game continues } \\
\text { until the last slip is taken. }\end{array}$ & $\begin{array}{l}\text { Technical } \\
\text { vo-cabulary. }\end{array}$ \\
\hline 13 & $\begin{array}{l}\text { Gap-fill } \\
\text { games }\end{array}$ & $\begin{array}{l}\text { A missing word } \\
\text { Students fill up the missing term in a sentence }\end{array}$ & $\begin{array}{c}\text { Technical } \\
\text { vo-cabulary. }\end{array}$ \\
\hline 14 & $\begin{array}{l}\text { Anagrams } \\
\text { Arranging } \\
\text { acti-vities }\end{array}$ & $\begin{array}{l}\text { Jumbled words } \\
\text { Students are asked to arrange jumbled words into } \\
\text { sen-tences }\end{array}$ & $\begin{array}{c}\text { Technical } \\
\text { vo-cabulary. }\end{array}$ \\
\hline
\end{tabular}


sure about the importance of English for their professional success (100\% for both groups). In general, both groups demonstrated high level of motivation in using lexical games for technical vocabulary acquisition.

Most of the students agreed that they feel less anxiety when communicating in the course of game activity (group A 88\%; Group B $92 \%$ ), thus highly evaluating the benefits they get from using games in learning ME (group A 100\%; Group B 92\%). Students also found that the content of the games matched the ME syllabus.

The findings proved positive effect of educational games in developing stu-dents' memory skills and critical thinking (group A 100\%; Group B $83 \%$ ). Students showed their interest in solving the given problems set in the games (group A 100\%; Group B 84\%); the majority in both groups found this process encouraging (100\% and $88 \%$ respectively). Both groups of respondents agreed that educational games are challenging their understanding of the subject (group A88\%; Group B 91\%).

Game-based approach to learning resonates with most students (group A 100\%; Group B 100\%), showing their wish to practice educational games more often in other learning activities (group 100A \%; Group B 84\%). Students also wish that the games would make a part of their home tasks, individual tasks, projects, etc.

In summary, all the respondents in Group A and Group B confirmed their positive response on the use of educational lexical games in Maritime Engineering English learning, namely specialized vocabulary mastering. Besides, the use of games in class was highly rated by both the first-year students, who are at square one in their studies, and fourthyear cadets, most of whom are completing their graduation. It means that educational games can be effectively used in various contexts however highly specialized they are.

The survey on the participants' perception of the effectiveness of the selected lexical educational games of various types for mastering technical vocabulary showed that the students ranked the games to their efficiency as follows: 1. Guessing games. 2. Categories games. 3. Matching games. 4. Spelling games. 5. Anagrams, arranging activities and crosswords (due to their low pace and time-consuming nature). The students demonstrated a high tendency in believing that educational games are able to provide opportunities towards their learning. 


\section{Conclusions and Recommendations}

This research proved that students view educational games as a positive motivational strategy in Maritime English vocabulary acquisition. The benefits of a game-based approach to teaching Specialized English to marine engineering stu-dents are obvious: educational games keep students' focus on learning process in an enjoyable learning atmosphere; they contribute to their cognitive development in terms of better memory, critical thinking, creativity and self-expression. Games are fun, inspiring, teaching, and promoting language fluency activities. And they draw even more to be worth of using in an English classroom. But if not for any of these reasons, they should be used "...just because they help students see beauty in a foreign language and not just problems that at times seem overwhelming" $[37$, p. 21].

The findings of this survey fit well into outcomes obtained by other researchers referred to in this paper in the field of educational games implementation in teaching GE, ESP, other subjects (programming, economics studies, etc.), both in class and with the use of online technologies $[5 ; 6 ; 15 ; 16 ; 19 ; 21 ; 26]$.

This research analyzed the vocabulary educational games which were favored by the participants of this study in context of their effectiveness for mastering technical vocabulary. Thus, the recommendations on the choice of lexical educational games, which will appeal to students and meet their demands, are as follows: guessing, matching and categories games got the highest rating among the students. The variety of these types of lexical games is very large, so the teacher has a wide choice of means. In case of spelling games, anagrams and crosswords, the students featured required time resource and leisurely pace of these games as less appropriate in the process of learning and revising technical vocabulary in class. Though, they can be used for independent work of students (home tasks, projects, etc.).

This research can be furthered and expanded in the field of developing a wider selection of educational games constituting the part of the current ME course, along with practical recommendations on their use. The progress in e-learning provides perspectives for their online realization.

E. Reyes-Chua [30, p. 127] developed guidelines for a teacher with respect to implementation of educational games in the classroom, among which are the following: 
- combine a game-based approach with other existing teaching methods;

- avoid overloading lessons with games;

- use the games as instructive strategies;

- take account of students' learning styles;

- take into consideration age and cultural backgrounds of learners, their health status;

- consider learning settings and the time duration;

- focus on realization of the lesson learning objectives;

- observe and reflect on class participation and interaction;

- variate games;

- integrate other techniques if possible;

- fun and enjoyment should not be over learning;

- manage to improvise and adapt to the situation, if needed.

It should be noted, that these recommendations well suit for the context of Maritime Engineering English classroom.

Being one of the effective ways to develop teaching pedagogies with the purpose of offering more opportunities for student learning, a game-based approach should be combined with other reliable teaching methods. At the National University "Odessa Maritime Academy", we use a game-based approach in teaching Maritime English to cadets along with other effective teaching strategies and means (communicative and competence approach, problematic approach, method of project, information technologies, smart boards, multimedia language learning centres, etc.), aimed at students' mastering the required ME proficiency.

This research is going to be continued in the field of role-playing in teaching Maritime English, including the approbation of the new course on intercultural competence, which is in progress and gets highly positive attitude from learners. The outcomes of the complex research will let to introduce changes to Maritime Engineering English teaching methods with the account of world shipping market requirements to seafarers. Along with it, the author is planning to consider the extremely fast development of e-learning, which shall be reflected in the issue of game-based approach to teaching ME.

In the author's opinion, along with the implementation of a gamebased approach, the ME syllabus should provide GE content prior to ME, thus making the basis for ESP 'superstructure'. The use of educational 
games for vocabulary acquisition and role-plays for deeper understanding of professional aspects are expected to lead to positive changes and improvements in education of future seamen, which will make the process of Maritime English acquisition by students more effective and exciting.

\section{References:}

1. Anderson, T., Dron, J. (2012). Learning technology through three generations of technology enhanced distance education pedagogy. European Journal of Open, Distance and E-Learning, vol. 15, no. 2, pp. 1-14.

2. Bocanegra-Valle, A. (2013). Maritime English. In C.A.Chappelle (Ed.). The Encyclopedia of Applied Linguistics, pp. 3570-3583. Hoboken: Blackwell Publishing Ltd. Available at: doi.org/10.1002/9781405198431.wbeal0746 (accessed 6 May 2020).

3. Bogart, W.V.D. (2009). Developing a pedagogy for active learning (PAL) including a brief history for active learning in Thailand. Journal of studies in the English language, vol. 4. Available at: http://www.earthportals.com/Portal Messenger/ActiveLearning.html (accessed 7 May 2020).

4. Bush, J. (2015). The impact of classroom games on the acquisition of second language grammar. LIF - Language in Focus Journal, vol. 1, no. 2. Available at: doi.org/10.1515/lifijsal-2015-0007 (accessed 5 May 2020).

5. Cam \& Tran (2017). An evaluation of using games in teaching English grammar for first year English-majored students at Dong Nai Technology University International Journal of Learning, Teaching and Educational Research, vol. 16, no. 7 , pp. 55-71.

6. Chudajkina, G.M., Loginova, N.Y. (2017). Ispolzovaniye rolevykh igr v prepodavanii inostrannogo yazyka $\mathrm{v}$ vuzah turizma I servisa. Vestnik associacii vuzov turizma I servisa, vol. 11, no. 2, pp. 13-20. Available at: https://cyberleninka.ru/article/n/ispolzovanie-rolevyh-igr-v-prepodavanii-inostrannogo-yazyka-v-vuzah-turizma-i-servisa (accessed 9 May 2020).

7. Cohen, L., Manion, L. \& Morrison, K. (Ed.) (2007). Research methods in education. ( $6^{\text {Th }}$ ed.). New York: Routledge.

8. Constantinescu, R.S. (2012). Learning by playing. Using computer games in teaching English grammar to high school students. Proceeding of the eLearning \& Software for Education: International Scientific Conference (Romania, Bucharest, April 26-27, 2012), Bucharest: Editura Universitara, pp. 110-115. Available at: doi: 10.5682/2066-026X-12-109 (accessed 1 May 2020).

9. Crookal, D., Oxford, R. (1990). Simulation, gaming, and language learning. New York: Newbury House Publishers.

10. Crookes, G., Schmidt, R. (1985). Motivation: Reopening the research agenda. Language Learning, vol. 41, pp. 469-512.

11. Debreli, E. (2012). Change in beliefs of pre-service teachers about teaching and learning English as a foreign language throughout an undergraduate pre-service teacher training program. Procedia Social and Behavioral Science, 46, 367-373. 
12. Derakhshan, A. \& Khatir, E. (2015).The effects of using games on English vocabulary learning. Journal of Applied Linguistics and Language Research, vol. 2, no. 3, pp. 39-47. Available at: http://jallr.com/index.php/JALLR/article/ view/40 (accessed 25 April 2020).

13. Dolnicar, S. \& Grun, B. (2013). Translating between survey answer formats. Journal of Business Research, vol. 66, pp. 1298-1306. Available at: https://fdfgroup.ru/statyi/-Translating--between-survey-answer-formats_2013 Journal-of-Business-Researc.pdf (accessed: 3.05.2020)

14. Gardner, R. \& Clement, R. (1990). Social psychological aspects of second language acquisition. Handbook of Language and Social Psychology, vol. 1. Available at: https://www.researchgate.net/publication/232441381_Social_psychological_perspectives_on_second_language_acquisition (accessed 9 May 2020).

15. Gozcu, E. \& Caganaga, C., K. (2016). The importance of using games in EFL classrooms. Cypriot Journal of Educational Science, vol. 11, no. 3, pp. 126-135. Available at: http://sproc.org/ojs/index.php/cjes/ (accessed 8 May 2020).

16. Guerid, F. (2015). Enhancing Students' Level of Motivation in Learning English: The Case of 1st Year's Economics Students. International Journal of Languages, Literature and Linguistics, vol. 1, no. 3, pp. 188-192.

17. Hadfield, J. (1999). Intermediate Communication Games. Spain: Addison Wesley Longman Ltd.

18. Harris, C. (2009). Meet the new school board: Board games are back and they're exactly what your curriculum needs. School Library Journal, vol. 55, pp. 24-26.

19. Ibrahim, R., Rasimah, C.M.Y., Hasiah, M., Azizah, J. (2011). Students Perceptions of Using Educational Games to Learn Introductory Programming. Computer and Information science, vol. 4, no. 1, pp. 205 - 216. Available at: https://www.researchgate.net/publication/49594530_Students_Perceptions_of_Using Educational_Games_to_Learn_Introductory_Programming (accessed 9 May 2020).

20. Johns, A., Düdley-Evans, T. (1991). English for Specific Purposes: International in Scope, Specific in Purpose. TESOL Quarterly, vol. 25, no. 2, pp. 297-314.

21. Kegalj, J., Jokić-Kuduz, A. (2018). How to Make Teaching Maritime English (More) Interesting? Proceedings of the Languages for Specific Purposes: Opportunities and Challenges of Teaching and Research: $1^{\text {st }}$ international conference (Slovenia, Ljubljana, May 19-20, 2017) (ed: Slavica Cepon), Ljubljana, pp. 45-55.

22. Kim, L.S. (1995). Creative Games for the Language Class. Forum, vol. 33, no. 1, pp. 35-36.

23. Kühn S., Lorenz R., Banaschewski T., Barker G. J., Büchel C., Conrod P. J., et al. (2014). Positive association of video game playing with left frontal cortical thickness in adolescents. Available at: PLoS ONE 9:e91506.10.1371/journal. pone.0091506 (accessed 6 May 2020).

24. Lee, W.R. (ed.) (1989). Language teaching. Games and Contests. ( $2^{\text {nd }}$ ed.). Hong Kong: Oxford University Press.

25. Lukianenko,V. (2015). The advantages of using games in foreign language teaching and learning. Proceedings of the Suchasni pidkhody ta innovaci- 
jni tendenciji $u$ vykladanni inozemnykh mov: $10^{\text {th }}$ international scientific-practical conference (Ukraine, Kyiv, March 24, 2015), vol. 3, Kyiv. Available at: http://interconf.fl.kpi.ua/node/1271 (accessed 8 May 2020).

26. Madrid, D. (2002). The Power of the FL Teacher Motivational Strategies. CAUCE: Revista de Filología y su Didáctica, vol. 25, pp. 369 - 422. Available at: https://www.researchgate.net/publication/28169562_The_power_of_the_FL_ teacher's motivational_strategies (accessed 6 May 2020).

27. Miles, M.B., Hūberman, A.M. (1994). Qualitative data analysis. California: SAGE.

28. Nation, I. S. P. (1990). Teaching and learning vocabulary. New York: Newbury House Publishers.

29. Reilly, E., Buskist, C., \& Gross, M. K. (2012). Movement in the classroom: Boosting brain power, fighting obesity. Kappa Delta Pi Record, vol. 48, no. 3, pp. 62-66.

30. Reyes-Chua, E., Lidawan, M.W. (2019). Games as effective ESL language classroom strategies: a perspective from English major students. European Journal of Foreign Language teaching, vol. 4, no. 1, pp. 111-130. Available at: www.oapub.org/edu (accessed 9 May 2020).

31. Richard-Amato, P. A. (1988). Making it happen: Interaction in the Second Language classroom: From Theory to Practice. New York: Longman.

32. Skehan, P. (1989). Individual Differences in Second Language Learning. London, Edward Arnold.

33. Spolsky, B. (1985). Formulating A Theory Of Second Language Learning. Studies in Second Language Acquisition, vol. 7, no. 3, pp. 269-288. Available from: www.jstor.org/stable/44488562 (accessed 7 May, 2020).

34. Stronin, M.F. (1984). Obuchayushchie igry na uroke angliyskogo yazyka. Moscow: Prosveshchenie.

35. Tominac, S. (2008). A Trial Test of Maritime English Competence TOMEC. Proceedings of The Role of Maritime English - Promoting communication and understanding culture: 20th International Maritime English Conference (China, Shanghai, October 27-30, 2008). Shanghai, pp. 149-164.

36. Tomlinson, B. (2011). Materials Development in Language Teaching. Cambridge: Cambridge University Press.

37. Uberman, A. (1998). The use of games: for vocabulary presentation and revision. English Teaching Forum, vol. 36, no. 1, pp. 20-27. Available at: http://exchanges.state.gov/forum/vols/vol36/no1/p20.htm (accessed 8 May 2020).

38. Volkhonskaya A.S., Klimenko, E.B. (2018). Ispolzovanie rolevykh igr v realizatsii kommunikativnogo podkhoda $\mathrm{v}$ obuchenii inostrannomu yazyku studentov tekhnicheskogo vuza. Sovremennye problem nauki I obrazovaniya, vol. 2. Available at: http://www.science-education.ru/ru/article/view?id=27485 (accessed: 07.05.2020).

39. Williamson, K. M., Land, L., Butler, B., \& Ndahi, H. B. (2004). A structured framework for using games to teach mathematics and science in K-12 classrooms. The Technology Teacher, vol. 64, pp. 15-18. 